\title{
ANALISIS KEMAMPUAN SISWA DALAM PEMECAHAN SOAL CERITA PADA MATA PELAJARAN MATEMATIKA KELAS VDI SDN 5 OLEAN PADA MASA PANDEMI COVID-19 KABUPATEN SITUBONDO TAHUN AJARAN 2020/2021
}

\author{
Hanif $^{1}$, Mory Victor Febrianto ${ }^{2}$ \\ ${ }^{1,2}$ Fakultas Keguruan dan Ilmu Pendidikan Unars \\ E-mail: hanifgenset16@gmail.com
}

Received: Sept 14, 2021 Revised: Sept 20, 2021 Accepted: Oct 5, 2021

\begin{abstract}
ABSTRAK
Penelitian ini dilatarbelakangi oleh pada proses pembelajaran matematika siswa saat mengerjakan soal cerita lebih banyak menggunakan model polya atau tidak. Penelitian ini bertujuan untuk mengetahui tentang kemampuan siswa dalam pemecahan soal cerita pada mata pelajaran matematika kelas V di SDN 5 Olean Kabupaten Situbondo. Metode penelitian yang digunakan dalam skripsi ini adalah deskriptif kualitatif. Subyek penelitian sebanyak 5 siswa yaitu UM, MR, PD, ZH dan RH. Penelitian pertama saat mengerjakan soal, semua siswa tidak sesuai dengan keempat indikator dikarenakan siswa tidak dibiasakan oleh guru dalam memakai cara tersebut. Pada penelitian kedua, ada 2 siswa yang memahami soal cerita dan merencanakan penyelesaian yang diberikan oleh peneliti. Sedangkan umtuk 3 siswa lainnya kurang memahami soal yang diberikan. Pada penelitian ketiga dan keempat, semua siswa telah paham terhadap soal yang diberikan oleh peneliti. Semua siswa mampu mengerjakan soal dengan menuliskan komponen "diketahui" dan komponen "ditanya". Dalam kemampuan merencanakan masalah, siswa telah dapat merencakan masalah pada saat dilakukannya penelitian ketiga dan keempat. Kemampuan melaksanakan rencana pemecahan masalah merupakan kemampuan setelah siswa menuliskan perencanaan. semua siswa sudah mampu menuliskan hal-hal yang diketahui dari soal secara lengkap. Siswa sudah dapat menghitung dengan benar. Dalam kemampuan menyimpulkan kembali, siswa sudah mampu menyimpulkan atau menulis kembali jawaban yang sudah diperoleh.
\end{abstract}

Kata Kunci: Kemampuan Siswa, Pemecahan Soal Cerita, Pembelajaran Matematika

\section{PENDAHULUAN}

Pada tahun 2020 Indonesia sedang dilanda wabah yaitu dimana wabah tersebut membawa pengaruh besar terhadap dunia pendidikan yang ada di indonesia. Dari pandemi covid-19 ini, Pemerintah menerapkan kebijakan yaitu Work From Home (WFH). Kebijakan ini merupakan upaya yang diterapkan kepada masyarakat agar dapat menyelesaikan segala pekerjaan di rumah. Pendidikan di Indonesia pun menjadi salah satu bidang yang terdampak 
akibat adanya pandemi covid-19 tersebut. Dari proses pembelajaran online tersebut sangat berdampak terhadap siswa, orang tua dan guru itu sendiri.

Pembelajaran merupakan bantuan yang diberikan pendidik agar terjadi proses pemerolehan ilmu dan pengetahuan,penguasaan, kemahiran, dan tabiat, serta pembentukan sikap dan keyakinan pada peserta didik.(Hanafy, 2014:74)

Matematika adalah ilmu yang membahas angka-angka dan perhitungannya, membahas masalah-masalah numerik, mengenai kuantitas dan besaran, mempelajari hubungan pola, bentuk dan struktur, sarana berfikir, komponen sistem, struktur, dan alat (Ismail, 2000:13).

Siswono dalam (Nursha et al., 2017:1)menyatakan bahwa tujuan pembelajaran matematika di sekolah adalah untuk melatih cara berpikir dan bernalar dalam menarik kesimpulan, yang didukung oleh struktur kurikulum pendidikan dasar di Indonesia yang berisi tentang muatan pembelajaran yang dirancang untuk mengembangkan kompetensi sikap operasional dan pengetahuan, keterampilan, dan sosial. Tujuan pendidikan matematika di sekolah lebih ditekankan pada penataan nalar, dasar dan pembentukan sikap serta keterampilan dalam penerapan matematika.

Kemampuan penalaran ada keterkaitannya dengan soal cerita matematika, karena dalam menyelesaikan soal cerita siswa dituntut untuk berfikir secara bernalar hal ini diperkuat dengan pernyataan (Linola, 2017) bahwa dalam menyelesaikan soal cerita matematika siswa tidak hanya sekedar memperoleh hasil jawaban dari hal yang ditanyakan, tetapi yang lebih penting siswa harus mengetahui dan memahami proses berpikir atau langkah- langkah untuk mendapatkan jawaban tersebut. Pemberian soal berbentuk cerita dalam matematika sulit untuk diselesaikan, karena kurangnya kemampuan siswa dalam mengubah kalimat verbal menjadi notasi matematika dan kurangnya kemampuan siswa dalam menentukan hal apa saja yang harus dilakukan terlebih dahulu pada saat menyelesaikan soal cerita.

Salah satu model pemecahan yang dapat digunakan untuk memecahkan soal cerita pada matematika adalah model pemecahan polya. Karena pada pembelajaran matematika, siswa sering dihadapi pemecahan masalah dalam bentuk soal cerita, dalam soal cerita tersebut siswa dituntut untuk mengetahui apa yang diketahui serta ditanyakan pada soal tersebut. Model pemecahan polya merupakan sebuah yang dapat membantu siswa dalam memecahkan soal cerita matematika dengan langkah-langkah penyelesaian yang baik dan benar.

Berdasarkan observasi awal yang peneliti lakukan di SDN 5 Olean Kabupaten Situbondo, alasan peneliti tertarik untuk melakukan penelitian di SDN 5 Olean karena 
peneliti ingin mengetahui pada proses pembelajaran matematika saat mengerjakan soal cerita seberapa paham siswa terhadap soal tersebut dan juga lebih banyak menggunakan model polya atau tidak. Berangkat dari permasalahan-permasalahan tersebut, Penulis tertarik untuk melakukan penelitian tentang "Analisis Kemampuan Siswa Dalam Pemecahan Soal Cerita Pada Mata Pelajaran Matematika kelas V di SDN 5 Olean Pada Masa Pandemi Covid-19 Kabupaten Situbondo.”

\section{METODE PENELITIAN}

Jenis penelitian ini menggunakan penelitian kualitatif. Pendekatan yang digunakan dalam penelitian ini adalah pendekatan deskriptif kualitatif. Jenis penelitian kualitatif digunakan dalam penelitian ini untuk mengetahui kemampuan siswa dalam pemecahan soal cerita pada mata pelajaran matematika kelas V di SDN 5 Olean Pada masa pandemi covid-19 Kabupaten Situbondo.

Penelitian ini dilaksanakan di SDN 5 Olean. Peneliti memilih lokasi penelitian di SDN 5 Olean untuk mengetahui kemampuan siswa dalam pemecahan soal cerita pada mata pelajaran matematika kelas $\mathrm{V}$

Adapun sumber data yang diambil yaitu:

1) Sumber Data Primer

Sumber data primer adalah data yang diperoleh atau dikumpulkan secara langsung oleh peneliti dari lapangan. Data primer dapat diperoleh secara langsung dari obyek yang diteliti dengan cara diambil dan kemudian diolah sendiri oleh peneliti sehingga mendapatkan kesimpulan. Adapun data yang diperoleh adalah dari hasil wawancara, observasi dan dokumentasi.

Tabel 3.1 Kode informan

\begin{tabular}{|c|l|l|l|}
\hline No & \multicolumn{1}{|c|}{ Nama } & Status & \multicolumn{1}{|c|}{ Kode } \\
\hline 1 & Sudiharto & Guru & ST \\
\hline 2 & Ulfatul Mawaddah & Siswa & UM \\
\hline 3 & Putri Dwi Hanifa & Siswa & PD \\
\hline 4 & Muhammad Ridwan & Siswa & MR \\
\hline 5 & Zainullah & Siswa & ZH \\
\hline 6 & Moch. Raihan Taufiqul Hakim & Siswa & RH \\
\hline
\end{tabular}


2) Sumber Data Sekunder

Data sekunder dapat diperoleh secara tidak langsung dari sumber penelitian. Adapun sumber data sekunder yang dibutuhkan seperti data-data guru maupun peserta didik, foto/gambar, dokumen dapat berupa catatan pribadi, buku. Data sekunder ini untuk memperkuat penemuan dan melengkapi informasi yang telah dikumpulkan.

Proses pengumpulan data menggunakan 3 cara yaitu wawancara, observasi dan dokumentasi. Teknik analisis data yang digunakan dalam penelitian ini adalah analisis kualitatif yang digunakan peneliti sebagaimana yang dikemukakan Miles dan Hubberman (Sugiyono, 2007: 204) yaitu pengumpulan data, reduksi data, penyajian data dan langkah terakhir adalah penarikan kesimpulan.

\section{HASIL DAN PEMBAHASAN}

Observasi pertama dilaksanakan pada hari rabu tanggal 21 April 2021. Observasi dilakukan pada siswa saat pembelajaran matematika, peneliti mengobservasi 5 siswa di kelas 5 yaitu UM, MR, PD, ZH dan RH. Peneliti telah melakukan tes tertulis sebanyak 4 kali. Tes pertama peneliti memberikan sebanyak 5 soal yang diujikan. 5 soal tersebut yaitu terdiri dari bilangan operasional, pecahan, kecepatan, skala dan volume. Dari 5 soal tersebut dalam menjawab soal kurang tepat dan belum paham dalam kemampuan memahami masalah pada soal cerita. Serta siswa tidak menuliskan komponen "diketahui" dan komponen "ditanya" tetapi siswa hanya langsung menjawab jawabannya saja tanpa memakai cara apapun.

Observasi kedua dilaksanakan pada hari kamis tanggal 22 April 2021. Tes kedua juga dilakukan sebanyak 5 soal yang diujikan dengan soal yang sama seperti tes pertama. Sebelum soal disajikan kepada siswa, peneliti memberikan contoh terlebih dahulu tentang cara mengerjakannya yang didalamnya sudah terdapat kata komponen "diketahui", komponen "ditanya" dan cara mengerjakannya. Setelah peneliti memberi contoh 1 soal, siswa dipersilahkan untuk mengerjakan soal-soal yang telah disiapkan kepada siswa. Pada tes kedua MR, ZH dan RH mereka belum menggunakan kata komponen "diketahui" dan komponen "ditanya". Pada saat pengumpulan sebagian siswa sudah paham yang "diketahui" dan yang "ditanya". Akan tetapi siswa masih bingung dalam menjawab. Dari 5 siswa ada 3 yang masih belum paham terhadap komponen "diketahui" dan komponen "ditanya".

Observasi ketiga dilaksanakan pada hari selasa tanggal 25 Mei 2021. Tes ketiga sebanyak 1 soal yang diujikan. Soal tersebut tentang statistik yang dalam minggu ini sudah dipelajari oleh siswa. Hasil dari 5 siswa tersebut sudah memenuhi apa yang diharapkan yaitu semua siswa sudah mengisi dengan kata komponen "diketahui" dan komponen "ditanya" 
beserta jawaban yang mereka peroleh jawabannya adalah benar. Karena siswa sudah mulai paham maksud dari soal yang disajikan. Hal tersebut dikarenakan siswa telah ketiga kalinya membiasakan menggunakan kata-kata komponen "diketahui" dan komponen "ditanya”.

Observasi keempat dilaksanakan pada hari kamis tanggal 27 Mei 2021. Pada tes terakhir atau ke-4 sebanyak 1 soal yang diujikan meneruskan materi yang kemarin yaitu tentang statistik. Peneliti langsung memberikan soal tersebut tanpa memberi contoh terlebih dahulu dan meminta siswa mengerjakannya. Sama seperti pada tes ketiga peneliti hanya memberi waktu 30 menit untuk mengerjakannya. Dalam waktu kurang lebih 20 menit siswa telah selesai mengerjakannya. Hasilnya adalah siswa telah biasa menggunakan kata " komponen "diketahui" dan komponen "ditanya". Serta jawaban dari soal tersebut semua dijawab dengan benar. Hal itu dikarenakan siswa mulai paham terhadap soal yang disajikan.

Hasil wawancara dengan guru kelas 5 mengenai tanggapan siswa terhadap pembelajaran matematika, dimana siswa banyak yang kurang minat terhadap pembelajaran matematika. Hal tersebut yang membuat hampir semua siswa masih tidak terlalu paham pada pembelajaran matematika, tetapi ada beberapa materi yang membuat banyak siswa paham. Materi-materi tersebut yaitu tentang akar pangkat tiga, pecahan dan bangun datar.

Guru membimbing siswa pada saat mengerjakan soal cerita dan memberikan perhatian lebih kepada siswa yang susah dalam mengerjakan soal tersebut. Guru menilai siswa paham tidaknya dalam mengerjakan soal yaitu dengan cara dilihat dari jawaban siswa serta pada saat proses mengerjakannya. Untuk mengetahui kemampuan siswa kelas 5 dalam membuktikan bahwa perhitungan yang mereka peroleh sudah tepat yaitu dengan cara membahas bersama-sama untuk benar tidaknya jawaban tersebut. Menurut guru Siswa masih mengalami kesulitan pada saat mengerjakan soal cerita. Hal yang menyebabkan siswa mengalami kesulitan tersebut karena siswa masih banyak yang kurang memahami kalimat soal cerita

\section{Analisis Proses Pembelajaran Pada Masa Pandemi}

Proses pembelajaran di SDN 5 Olean pada masa pandemi ini menggunakan 2 metode, yaitu luring dan daring. Luring dilaksanakan pada hari senin-kamis, sedangkan daring dilaksanakan pada hari jumat dan sabtu. Pelajaran yang dilakukan saat luring yaitu pembelajaran tematik dan matematika. Sedangkan pada saat daring pelajaran yang dilakukan yaitu Agama, Penjaskes, BTQ, Bhs madura dan Bhs inggris.

Selama pandemi, sekolah memberlakukan jadwal masuk kepada siswa. Siswa akan bergantian masuk sesuai jadwal yang diberikan sekolah. Sekolah membagi jadwal masuk 
menjadi 2 sesi sesuai absen. Hal itu terjadi juga pada kelas V, di kelas V terdapat 18 siswa sehingga guru membagi menjadi 2 yaitu setiap hari akan masuk 9 orang di kelas tersebut. Pada hari senin dan rabu siswa yang memiliki nomer absen 1-9 masuk ke kelas untuk mengikuti pembelajaran. Sedangkan untuk nomer absen 10-18 masuk pada hari selasa dan kamis. Pada masa pandemi ini, guru memulai pembelajaran di kelas V pada pukul 07.00 sampai pukul 09.00 jadi hanya 2 jam proses pembelajaran yang dapat dilakukan di sekolah. Dikarenakan pandemi, tidak semua siswa masuk untuk mengikuti pembelajaran disekolah. Terkadang hanya mengikuti pembelajaran daring. Selama peneliti melakukan 4 kali tes, yang sering masuk hanya 5 siswa yaitu UM, PD, MR, ZH, dan RH

\section{Analisis Hasil Penelitian Siswa}

Penelitian pertama dilaksanakan pada hari rabu tanggal 21 April 2021. Penelitian dilakukan pada siswa saat pembelajaran matematika, peneliti melakukan penelitian pada 5 siswa di kelas 5 yaitu UM, MR, PD, ZH dan RH. Peneliti memberikan waktu 1 jam untuk mengerjakan soal yang disajikan. Siswa dipersilakan mengerjakan soal tepat pukul 08.00. Pada saat jam menunjukkan jam 9 yang berarti sudah 1 jam siswa mengerjakan. 5 siswa diminta untuk mengumpulkan hasil jawaban yang dikerjakannya dan dari 5 siswa tersebut dalam menjawab tidak memenuhi 4 indikator yaitu tentang kemampuan memahami masalah pada soal cerita, merencanakan penyelesaian, melaksanakan rencana yang tertulis, dan memeriksa proses penyelesaian soal dan hasil.

Penelitian kedua dilaksanakan pada hari kamis tanggal 22 April 2021. Tes kedua juga dilakukan sebanyak 5 soal yang diujikan dengan soal yang sama seperti tes pertama. Sebelum soal disajikan kepada siswa, peneliti memberikan contoh terlebih dahulu tentang cara mengerjakannya yang didalamnya sudah terdapat kata komponen "diketahui", komponen "ditanya" dan cara mengerjakannya. Setelah peneliti memberi contoh 1 soal, siswa dipersilahkan untuk mengerjakan soal-soal yang telah disiapkan kepada siswa. Pemberian waktunya juga sama yaitu hanya 1 jam. Siswa mulai mengerjakan pada pukul 08.00 sampai pukul 09.00.

Dari 4 indikator, ada 2 indikator yang sudah terpenuhi oleh 2 siswa yaitu indikator memahami masalah pada soal cerita dan merencanakan penyelesaian. Kedua siswa tersebut adalah UM dan PD. Sedangkan untuk siswa yang lain masih belum memenuhi 4 indikator yang ada yaitu tentang memahami masalah 
pada soal cerita, merencanakan penyelesaian, melaksanakan rencana yang tertulis, dan memeriksa proses penyelesaian soal dan hasil.

Penelitian ketiga dilaksanakan pada hari selasa tanggal 25 Mei 2021. Tes ketiga sebanyak 1 soal yang diujikan. Soal tersebut tentang statistik yang dalam minggu ini sudah dipelajari oleh siswa. Sebelum disajikan soal tersebut pada siswa, peneliti memberikan contoh cara mengerjakan yang menggunakan kata " komponen "diketahui" dan komponen "ditanya". Setelah memberikan contoh siswa diminta untuk mengerjakan soal yang disajikan. Dikarenakan hanya 1 soal yang disajikan kepada siswa, peneliti memberi waktu 30 menit untuk mengerjakan soal tersebut. Hasil dari 5 siswa tersebut sudah memenuhi 4 indikator yaitu tentang memahami masalah pada soal cerita, merencanakan penyelesaian, melaksanakan rencana yang tertulis, dan memeriksa proses penyelesaian soal dan hasil.

Penelitian keempat dilaksanakan pada hari kamis tanggal 27 Mei 2021. Pada tes terakhir atau ke-4 peneliti memberikan sebanyak 1 soal yang diujikan meneruskan materi yang kemarin yaitu tentang statistik. Peneliti langsung memberikan soal tersebut tanpa memberi contoh terlebih dahulu dan meminta siswa mengerjakannya. Sama seperti pada tes ketiga peneliti hanya memberi waktu 30 menit untuk mengerjakannya. Dalam waktu kurang lebih 20 menit siswa telah selesai mengerjakannya. Hasilnya adalah siswa telah memenuhi 4 indikator tersebut.

Dari 4 kali penelitian siswa tidak dapat memahami pada tes pertama dan tes kedua. Pada saat tes pertama siswa tidak paham dikarenakan saat proses pembelajaran guru tidak melakukan 4 indikator penyelesaian dalam mengerjakan soal cerita. Guru hanya memberikan cara yang sederhana sehingga siswa kurang paham dan tidak terbiasa mengerjakan soal dengan menggunakan 4 indikator tersebut.

Pada tes kedua sebelum diberikan soal oleh peneliti, peneliti memberikan contoh cara mengerjakan soal dengan menggunakan 4 indikator penyelesaian terlebih dahulu supaya siswa paham tehadap cara mengerjakannya. Setelah peneliti memberikan contoh, siswa diharapkan dapat menegerjakannya dengan benar. Pada saat mengerjakan soal yang diberikan oleh peneliti, dari 4 indikator hanya ada 2 siswa yang menggunakan 2 indikator penyelesaian. Sedangkan 3 siswa lainnya tidak menggunakan indikator penyelesaian tersebut 
Selama 4 kali penelitian siswa sering tidak paham pada indikator melaksanakan rencana yang tertulis dan memeriksa proses penyelesaian soal dan hasil. dikarenakan siswa tidak terbiasa membuktikan kebenaran jawaban, kurang teliti dalam hal perhitungan sehingga berdampak pada penarikan kesimpulan, tidak sering latihan di rumah, tidak memperhatikan guru ketika sedang mengajar karena kurang minat terhadap mata pelajaran matematika..

\section{Siswa Ulfatul Mawaddah (UM)}

Berdasarkan hasil wawancara guru dan siswa, UM memiliki minat dalam pembelajaran matematika. Pada saat proses mengerjakan soal yang disajikan selama 4 kali tes. UM sangat percaya diri terhadap hasil yang diperoleh. Dalam memahami soal, Pada saat observasi tes pertama, UM kurang memahami dalam menuliskan komponen "diketahui" dan komponen "ditanya" dari soal yang disajikan. Sedangkan tes kedua UM telah paham komponen "diketahui" dan komponen "ditanya" dari soal. Pada tes ketiga dan keempat UM sudah mampu menuliskan komponen "diketahui" dan komponen "ditanya" dari soal secara lengkap. Dalam wawancara, guru mengatakan UM dalam mengerjakan soal tidak begitu sering menggunakan komponen "diketahui" dan komponen "ditanya" karena mereka tidak dibiasakan menggunakan komponen-komponen tersebut.

Dengan demikian siswa bernama UM telah paham terhadap materi yang diberikan. Serta sudah terbiasa menggunakan komponen "diketahui" dan komponen "ditanya" dalam soal cerita.

\section{Analisis Siswa}

Berdasarkan hasil wawancara guru dan siswa, PD memiliki minat dalam pembelajaran matematika. Pada saat proses mengerjakan soal yang disajikan selama 4 kali tes. PD sangat percaya diri terhadap hasil yang diperoleh. Dalam memahami soal, PD saat tes pertama dan kedua masih tidak paham terhadap soal cerita yang disajikan. Sedangkan tes kedua PD telah paham komponen "diketahui" dan komponen "ditanya" dari soal. Pada tes ketiga dan keempat PD sudah mampu menuliskan komponen "diketahui" dan komponen "ditanya" dari soal secara lengkap. Dalam wawancara, guru mengatakan PD dalam mengerjakan soal tidak begitu sering menggunakan komponen "diketahui" dan komponen “ditanya" karena mereka tidak dibiasakan menggunakan komponen-komponen tersebut. 
Dengan demikian siswa bernama PD telah paham terhadap materi yang diberikan. Serta sudah terbiasa menggunakan komponen "diketahui" dan komponen "ditanya" dalam soal cerita.

\section{Analisis Siswa MR}

Berdasarkan hasil wawancara guru dan siswa, MR kurang memiliki minat dalam pembelajaran matematika. Hal itu diketahui ketika proses mengerjakan soal yang disajikan pada tes pertama MR mengerjakannya tepat waktu tetapi jawabannya dari 5 soal yang disajikan tidak semua benar. Pada saat observasi tes pertama, MR kurang memahami dalam menuliskan komponen "diketahui" dan komponen "ditanya" dari soal yang disajikan. Sedangkan tes kedua MR telah paham komponen "diketahui" dan komponen "ditanya" dari soal. Pada tes ketiga dan keempat MR sudah mampu menuliskan komponen "diketahui" dan komponen "ditanya" dari soal secara lengkap. Dalam wawancara, guru mengatakan MR dalam mengerjakan soal tidak begitu sering menggunakan komponen "diketahui" dan komponen "ditanya" karena mereka tidak dibiasakan menggunakan komponen-komponen tersebut.

Dengan demikian siswa bernama MR telah paham terhadap materi yang diberikan. Serta sudah terbiasa menggunakan komponen "diketahui" dan komponen "ditanya" dalam soal cerita.

\section{Analisis Siswa ZH}

Berdasarkan hasil wawancara guru dan siswa, ZH kurang memiliki minat dalam pembelajaran matematika. Pada saat observasi tes pertama, ZH kurang memahami dalam menuliskan komponen "diketahui" dan komponen "ditanya" dari soal yang disajikan. Sedangkan tes kedua $\mathrm{ZH}$ telah paham komponen "diketahui" dan komponen "ditanya" dari soal. Pada tes ketiga dan keempat ZH sudah mampu menuliskan komponen "diketahui" dan komponen "ditanya" dari soal secara lengkap. Dalam wawancara, guru mengatakan ZH dalam mengerjakan soal tidak begitu sering menggunakan komponen "diketahui" dan komponen "ditanya" karena mereka tidak dibiasakan menggunakan komponen-komponen tersebut.

Dengan demikian siswa bernama $\mathrm{ZH}$ telah paham terhadap materi yang diberikan. Serta sudah terbiasa menggunakan komponen "diketahui" dan komponen "ditanya" dalam soal cerita. 


\section{Analisis Siswa RH}

Berdasarkan hasil wawancara guru dan siswa, RH kurang memiliki minat dalam pembelajaran matematika. Pada saat observasi tes pertama, RH kurang memahami dalam menuliskan komponen "diketahui" dan komponen "ditanya" dari soal yang disajikan. Sedangkan tes kedua RH telah paham komponen "diketahui" dan komponen "ditanya" dari soal. Pada tes ketiga dan keempat RH sudah mampu menuliskan komponen "diketahui" dan komponen "ditanya" dari soal secara lengkap. Dalam wawancara, guru mengatakan RH dalam mengerjakan soal tidak begitu sering menggunakan komponen "diketahui" dan komponen "ditanya" karena mereka tidak dibiasakan menggunakan komponenkomponen tersebut.

Dengan demikian siswa bernama $\mathrm{RH}$ telah paham terhadap materi yang diberikan. Serta sudah terbiasa menggunakan komponen "diketahui" dan komponen "ditanya" dalam soal cerita.

\section{Analisis Kemampuan Memahami Masalah}

Peneliti memberikan soal kepada siswa yaitu UM, MR, PD, ZH dan RH. Selama empat kali melakukan tes, pada tes pertama semua siswa belum memahami soal yang disajikan oleh peneliti. Siswa juga tidak menuliskan kata komponen "diketahui" dan komponen "ditanya". selama tes kedua, ada beberapa siswa yang memahami tentang soal cerita yang disajikan peneliti. Dari 5 siswa hanya dua siswa yang mampu mengerjakan soal dengan menuliskan komponen "diketahui" dan komponen "ditanya”. Sedangkan pada tes ketiga dan keempat dari 5 siswa semuanya mulai memahami soal cerita yang disajikan oleh peneliti.

Berdasarkan data temuan dilapangan, semua siswa mampu mengerjakan soal dengan menuliskan komponen "diketahui" dan komponen "ditanya". Alasan mereka tidak memahami soal cerita yang disajikan oleh peneliti pada tes pertama dan kedua yaitu dikarenakan siswa telah mulai lupa terhadap materi-materi yang diajarkan sebelumnya oleh guru. Sedangkan pada tes ketiga dan keempat siswa paham terhadap soal cerita yang disajikan oleh peneliti. Dikarenakan materi yang disajikan ternyata telah dibahas dalam minggu sebelumnya.

Hal tersebut sesuai dengan pernyataan polya bahwa proses pemahaman masalah ditentukan dengan apa yang diketahui dan apa yang ditanyakan dalam soal, mengelola informasi dalam soal dan memilah-milah sesuai dengan peran masing-masing unsur dalam soal, serta bila perlu membuat gambar dan 
menuliskan notasi yang sesuai dimaksudkan untuk mempermudah memahami soal dan mempermudah gambaran umum penyelesaiannya.

\section{Analisis Kemampuan Merencanakan Masalah}

Dalam rencana permasalahan diperlukan suatu model. Model ini berbentuk data yang ada dengan apa yang ditanyakan. Untuk kemampuan merencanakan masalah siswa telah dapat merencakan masalah pada saat dilakukannya tes ketiga. Sedangkan pada tes awal siswa belum dapat merencanakan masalah yang terdapat pada soal cerita. Dikarenakan pada tes awal siswa belum memahami soal cerita yang disajikan oleh peneliti. Siswa dapat menyusun model matematika karena jika mereka sudah memahami masalah soal cerita maka mudah juga dalam menyusun model matematikanya.

Hal tersebut sesuai dengan pernyataan polya bahwa dalam rencana permasalahan diperlukan suatu model. Model ini berbentuk data yang ada dengan apa yang ditanyakan. Model ini merupakan interpretasi dari bahasa persoalan ke bahasa matematika. Proses perencanaan penyelesaian dilakukan dengan mencari hubungan antara data yang diberikan dengan data yang diketahui.

\section{Analisis Kemampuan Melaksanakan Rencana Pemecahan Masalah}

Kemampuan melaksanakan rencana pemecahan masalah merupakan kemampuan setelah siswa menuliskan perencanaan. Dua siswa mulai menuliskan komponen "ditanya" dalam soal pada tes kedua, ketiga dan keempat. Untuk tiga siswa lainnya mulai menuliskan komponen "ditanya" dalam soal pada tes ketiga dan keempat. Sedangan pada tes pertama semua siswa tidak menuliskan tentang komponen "ditanya" dalam soal yang disajikan.

Hal tersebut sesuai dengan pernyataan polya bahwa dalam menyelesaikan suatu soal cerita, melaksanakan rencana dapat berupa melakukan komputasi dari model matematika yang telah dibuat pada langkah kedua.

\section{Analisis Kemampuan Memeriksa Kembali Upaya Yang Diperoleh}

Dalam kemampuan ini siswa sudah mampu menyimpulkan atau menulis kembali jawaban yang sudah diperoleh. Dari kelima siswa yang diteliti, selama mengerjakan tes siswa sudah menggunakan kesimpulan atau menulis kembali jawaban yang sudah diperoleh. Hal tersebut sesuai dengan pernyataan polya bahwa pemeriksaan ini merupakan kegiatan menarik kesimpulan untuk mengembalikan jawaban sesuai konteks. 


\section{Analisis secara umum}

Peneliti melakukan penelitian kepada 5 siswa yaitu UM, MR, PD, ZH dan RH. Selama empat kali melakukan tes, siswa telah mampu memahami soal yang disajikan oleh peneliti. semua siswa mampu mengerjakan soal dengan menuliskan komponen "diketahui" dan komponen "ditanya". Dalam kemampuan merencanakan masalah, siswa telah dapat merencakan masalah pada saat dilakukannya tes ketiga. Kemampuan melaksanakan rencana pemecahan masalah merupakan kemampuan setelah siswa menuliskan perencanaan. semua siswa sudah mampu menuliskan hal-hal yang diketahui dari soal secara lengkap. Serta siswa sudah dapat menghitung dengan benar. Dalam kemampuan menyimpulkan kembali, siswa sudah mampu menyimpulkan atau menulis kembali jawaban yang sudah diperoleh.

\section{KESIMPULAN .}

Proses pembelajaran di SDN 5 Olean pada masa pandemi ini menggunakan 2 metode, yaitu luring dan daring. Luring dilaksanakan pada hari senin-kamis, sedangkan daring dilaksanakan pada hari jumat dan sabtu. Pelajaran yang dilakukan saat luring yaitu pembelajaran tematik dan matematika. Sedangkan pada saat daring pelajaran yang dilakukan yaitu Agama, Penjaskes, BTQ, Bhs madura dan Bhs inggris.

Pada saat melakukan penelitian kepada 5 siswa yaitu UM, MR, PD, ZH dan RH di SDN 5 Olean, selama penelitian pertama saat mengerjakan soal, semua siswa tidak sesuai dengan keempat indikator dikarenakan siswa tidak dibiasakan oleh guru dalam memakai cara tersebut. Pada penelitian kedua, ada 2 siswa yang memahami soal cerita dan merencanakan penyelesaian yang diberikan oleh peneliti. Sedangkan umtuk 3 siswa lainnya kurang memahami soal yang diberikan. Pada penelitian ketiga dan keempat, semua siswa telah paham terhadap soal yang diberikan oleh peneliti. Semua siswa mampu mengerjakan soal dengan menuliskan komponen "diketahui" dan komponen "ditanya". Dalam kemampuan merencanakan masalah, siswa telah dapat merencakan masalah pada saat dilakukannya penelitian ketiga dan keempat. Kemampuan melaksanakan rencana pemecahan masalah merupakan kemampuan setelah siswa menuliskan perencanaan. semua siswa sudah mampu menuliskan hal-hal yang diketahui dari soal secara lengkap. Siswa sudah dapat menghitung dengan benar. Dalam kemampuan menyimpulkan kembali, siswa sudah mampu menyimpulkan atau menulis kembali jawaban yang sudah diperoleh. 
Faktor yg menyebabkan siswa kurang memahami soal matematika tentang komponen "diketahui" dan komponen "ditanya" adalah guru matematika kelas 5 kurang membiasakan siswa dalam mengerjakan soal matematika dengan cara "diketahui" dan "ditanya". Yang mengakibatkan siswa kurang paham pada saat peneliti pertama kali memberikan sebuah test kepada siswa.

\section{DAFTAR PUSTAKA}

Hanafy, M. S, (2014). Konsep Belajar Dan Pembelajaran. Lentera Pendidikan : Jurnal Ilmu Tarbiyah Dan Keguruan, 17(1), 66-79. ㄴtps://doi.org/10.24252/lp.2014v17n1a5 Ismail dkk, Kapita Selekta Pembelajaran Matematika, Jakarta: Universitas Terbuka, (2000).

Nuirsha, G., Mirza, A., \& Bistari, (2017). Proses Berpikir Siswa dalam Menyelesaikan Soal Cerita Ditinjau dari Gaya Kognitif Materi Kubus dan Balok. Jurnal Pendidikan Dan Pembelajaran Khatulistiwa, 6(7), 1-7.

Linola, dkk, (2017). Analisis Kemampuan Penalaran Matematis Peserta Didik Dalam Menyelesaikan Soal Cerita di SMAN 6 Malang. Pi : Mathematics

Sugiyono, (2007). Metode Penelitian Kuantitatif Kualitatif dan R\&D. Bandung:Alfabeta. 